\title{
Anti-CD2 Monoclonal Antibody
}

National Cancer Institute

\section{Source}

National Cancer Institute. Anti-CD2 Monoclonal Antibody. NCI Thesaurus. Code C112882.

Any monoclonal antibody directed ag ainst the cell surface glycoprotein CD2, regardless of the antibody type. 